\title{
Application of Mooc-based Flipped Classroom in the Teaching Reform of Piano Course*
}

\author{
Tian $\mathrm{Shu}^{1}$ \\ Nanyang Institute of Technology
}

\begin{abstract}
Along with the deepening and reform of piano teaching, piano teaching resources have been optimized and integrated. The application of Internet technology provides a new opportunity for piano teaching mode and talents training in colleges and universities. Mooc teaching breaks the traditional teaching mode of group class and collective class, and flipped classroom can expand the piano subject practice. Based on the network technology, this study explores the application of the teaching mode of Mooc-based flipped classroom in the teaching reform of piano course. The results show that the teaching method of Mooc improves the ability of resources sharing, liberalization and teaching according to students' aptitude of piano teaching. The production of Mooc-based flipped classroom makes Internet knowledge and the dissemination of teaching break spacetime limit. Mooc platform is easier for students to apply their abilities to practical application. This study provides idea and platform for the combination of piano teaching and Internet in colleges and universities.
\end{abstract}

\section{Keywords}

Piano Teaching $\bullet$ Internet $\bullet$ Mooc Teaching $\bullet$ Flipped Classroom

\footnotetext{
*1. This paper is the final research result of Henan philosophy and social science planning project, project number: 2017 CYS036.

2. Bidding project of Henan government decision-making research in 2017: research on the connotation and path of Henan to build a national cultural highland project number: 2017 B366

3. This paper is the phased research results of the special project of Henan Province's key $r \& d$ and promotion project (scientific and technological breakthrough) in 2019. Project name: study on the cultural inheritance and communication path of local music resources in Henan from the perspective of new media

${ }^{1}$ Correspondence to: Tian Shu (MA), Conservatory of Music, Nanyang Institute of Technology, Nanyang 473000. China. Email: hiciq2007@163.com
} 
As a modern teaching carrier, the Internet has a very good function of optimization and penetration in the changing teaching reform (Yucetoker \& Apaydinli, 2012). The Internet has also played a positive role in music teaching, changing traditional teaching methods and starting a precedent for the diversity of music education (Egilmez, 2012). In music education, piano has become a good choice for people to learn music. As domestic demand for piano learning is increasing, more and more piano training institutions and private piano tutors have emerged in the society. The number of teachers is large, and the teaching level is uneven, lack of a reasonable teaching concept (Yeh, 2018; Ying, 2015). The piano teaching has strong practicalness. Along with the deepening of teaching reform, the combination of piano teaching and Internet is more and more closed, and the way for students to obtain teaching resources is more diversified and convenient so that student's knowledge and vision have been expanded (Hyrybeihammer, 2011).

The use of online classroom-assisted teaching changes the teaching mode of "teaching-centered". The short Mooc teaching videos meet the trend of the Internet era, which can adapt to students with mobile phone or computer learning habits. It breaks the barrier between classroom teaching and practice teaching, realizing the comprehensive integration of different teaching links (Villiers, 2012). The piano course teaching mode in the flipped classroom truly realizes the teaching according to student's aptitude. Students can master the study progress independently (Nevra, 2014). In the reform of piano course teaching of Mooc-based flipped classroom, teachers and students gradually attach importance to the teaching advantage brought by advanced internet technology for piano teaching (Griffith, Ramos, Hill \& Miguel, 2018). Many famous Mooc websites of piano teaching at abroad, such as Coursera and EDX, have brought piano network education into a new stage of development (Gouzouasis \& Ryu, 2015). Based on the network technology, this study explores the application of Mooc-based flipped classroom teaching mode in the teaching reform of piano course.

\section{Survey on the Cognition of Teaching Reform of the Informationized Piano Course for Teachers and Students in Colleges and Universities}

The teaching of piano should train high-level application-oriented technical talents with artistic performance, choreographing, wind music teaching and artistic comments (Marert, Delakowitz, Fränzle \& Wünschmann, 2017). This questionnaire survey mainly aims at five universities such as Nanjing Normal University, Yangzhou University and Yancheng Normal University, and 120 valid questionnaires are collected. Table 1 shows the teaching method of piano music for teachers. All can use piano collective teaching, playing and explaining. $80 \%$ of students say that teachers use multimedia to create situational teaching in music course teaching. Only $15 \%$ of students say that teachers use short videos to demonstrate their techniques. Table 2 shows the problems that students encounter in the learning of piano. The questionnaires show that the main problems students encounter in the learning of piano are poor improvisational performance ability and inflexible playing, which is difficult to express the beauty of music. A small part of students is unable to independently choose the appropriate playing techniques and difficult to play without music score. Table 3 is a survey of whether the Internet is likely to become the main development direction of piano teaching in the future. More than $80 \%$ think it is possible, and nearly $20 \%$ think it is not possible. 
Table 1

Teachers Use Piano Music Teaching Methods

\begin{tabular}{lccccc}
\hline Answer & $\begin{array}{c}\text { Collective teaching, } \\
\text { paradigm and } \\
\text { explanation }\end{array}$ & $\begin{array}{c}\text { Multimedia } \\
\text { creation } \\
\text { scenario }\end{array}$ & $\begin{array}{c}\text { Short video } \\
\text { demonstration playing } \\
\text { technique }\end{array}$ & $\begin{array}{c}\text { Group } \\
\text { discussion }\end{array}$ & Other \\
\hline People & 120 & 96 & 18 & 50 & 14 \\
Proportion & $100 \%$ & $80 \%$ & $15 \%$ & $44.67 \%$ & $11.67 \%$ \\
\hline
\end{tabular}

Table 2

Problems Encountered by Students in Piano Learning

\begin{tabular}{lccccc}
\hline Answer & $\begin{array}{c}\text { Cannot choose the } \\
\text { appropriate playing } \\
\text { method }\end{array}$ & $\begin{array}{c}\text { Hard to } \\
\text { play }\end{array}$ & $\begin{array}{c}\text { Difficulty in lifting } \\
\text { and lowering } \\
\text { numbers }\end{array}$ & $\begin{array}{c}\text { Playing } \\
\text { dull }\end{array}$ & $\begin{array}{c}\text { Poor } \\
\text { improvisation }\end{array}$ \\
\hline People & 25 & 27 & 23 & 52 & 96 \\
Proportion & $20.8 \%$ & $22.5 \%$ & $19.17 \%$ & $43.33 \%$ & $80 \%$ \\
\hline
\end{tabular}

Table 3

Whether the Internet is Likely to Become the Main Development Direction of Piano Teaching in the Future

\begin{tabular}{lcccc}
\hline Answer & Fully possible & More likely & Not likely & Impossible \\
\hline People & 33 & 66 & 14 & 1 \\
Proportion & $27.5 \%$ & $55 \%$ & $11.67 \%$ & $0.83 \%$ \\
\hline
\end{tabular}

\section{Piano Course Teaching from the Perspective of Internet Thinking}

\section{Establishing multi-collaborative learning thinking of piano Internet}

The questionnaires show that the current classroom teaching still focuses on collective teaching, and the current piano teaching in colleges and universities is facing the impact of the Internet, with great challenges and opportunities. The piano teaching should set up the open sharing piano education teaching idea. Teachers should encourage students to use the Internet to learn, actively playing their role of guidance and check. Moreover, teachers should change tradition and carry out leading-type teaching, fully mobilizing and giving full play to students' autonomy. The teaching of Mooc has the characteristics of sharing, participation and openness. The production of Mooc-based flipped classroom teaching makes the Internet knowledge production and dissemination of teaching break space-time limit. In the perspective of Internet thinking, teachers should constantly improve the level and ability of practice and application of their own Internet teaching, actively utilize Mooc-based flipped classroom, and provide the second classroom of learning for students with the Internet technology. In the Mooc-based flipped teaching, teachers' ability of Internet teaching piano has been constantly improved, students can carry out self-learning according to their own learning goals, learning difficulties and interests, thus ensuring the effective learning of students. To establish the multi-collaborative learning thinking of piano Internet, we should improve the learning quality of piano Internet, form the habit of systematic collaborative practicing piano, improve the ability of music appreciation with the help of Internet resources, and accumulate diversified music theory and cultural knowledge with Internet. 


\section{Building a participatory online piano teaching scene experience platform}

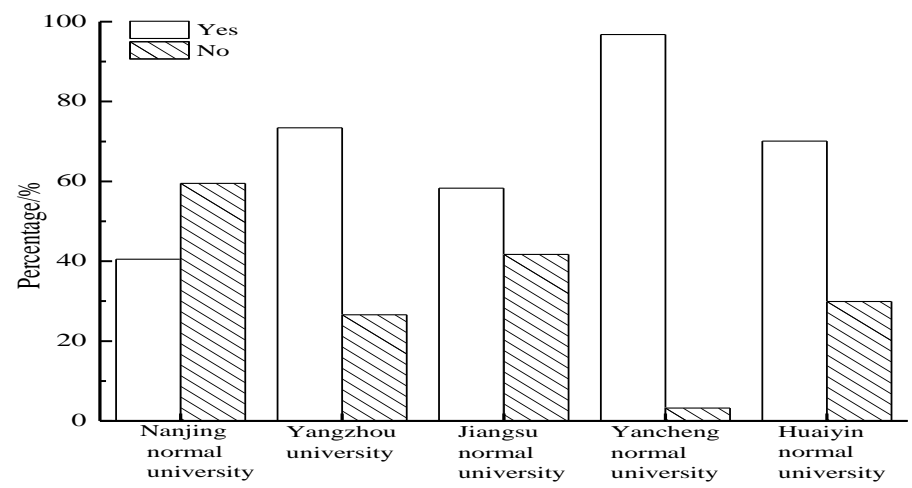

Figure 1. Uniform situation of music teaching materials in colleges and universities.

Figure 1 shows the uniform situation of music teaching materials in various colleges and universities. The five universities in the same province show different situations. The uniform situation of music teaching materials in Yancheng Normal University is relatively high while that in Nanjing Normal University is only $40 \%$. The main reason is that the Internet has become an important platform for piano teaching resources and learning. The piano teaching resources with Mooc as the learning platform have been gradually favoured by students, and the teacher-leading collective teaching mode has been gradually transformed into the teaching mode of online and offline equal dialogue so as to enhance students' participation in the piano teaching. Figure 2 is the distribution of students' ability value obtained in piano learning. Students' ability value is different in the teaching platform of different schools. For example, the students of Jiangsu Normal University have stronger visual performance ability while the students of Yangzhou University have stronger emotion handling ability. As a means of Internet teaching, Mooc has provided an important platform for piano teaching resources and learning, and the piano teaching function played by Mooc has become more and more important.

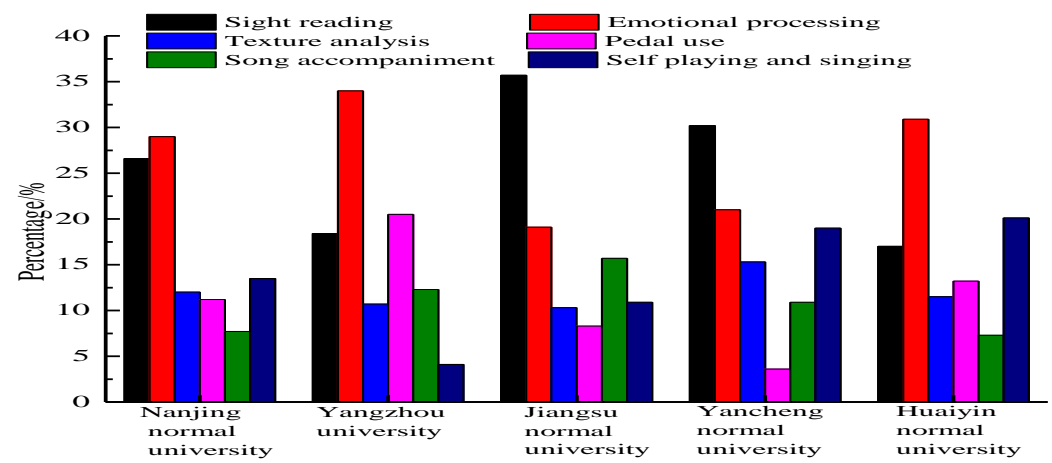

Figure 2. The distribution of abilities valued by students in piano learning. 


\section{Direction of the Reform and Construction of Network Informatization of Piano}

\section{Arming traditional classroom with piano "Mooc" teaching}

Figures 3-5 show the teaching methods of piano courses in Nanjing Normal University, Yangzhou University and Yancheng Normal University respectively. It can be seen that there are different teaching methods with different efficiency. Most of teaching methods are group class and collective class, making it difficult to take into account each student. Mooc teaching carries out video teaching by means of Internet medium, and integrates the important knowledge and teaching content in classroom. It is more targeted and the content is richer. With the deepening of Mooc teaching, there are many types of piano Mooc teaching, including pre-class, introduction class, teaching class and practice class. In the teaching of colleges and universities, Mooc attaches importance to the explanation of piano teaching video and performance video. The content is not necessarily close to the classroom teaching, and emphasizes the teaching method with diffusion. Teachers can use Mooc to expand the piano subject practice to realize the teaching effect of flipped classroom that is an important form of Mooc teaching. Students can use Mooc to make up their crux with pertinence and improve their ability to grasp the artistic characteristics and style of piano. By constantly enriching Mooc teaching resources and accumulating the reserve amount of piano teaching resources, teachers can not only integrate their own teaching resources, but also integrate the rich resources of the famous pianists, firmly consolidating students' professional foundation.

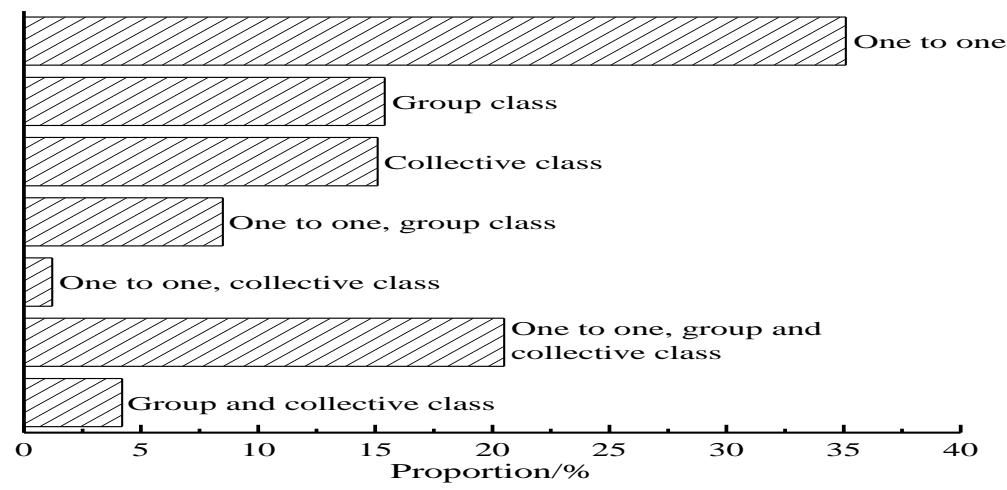

Figure 3. Nanjing Normal University piano course teaching method.

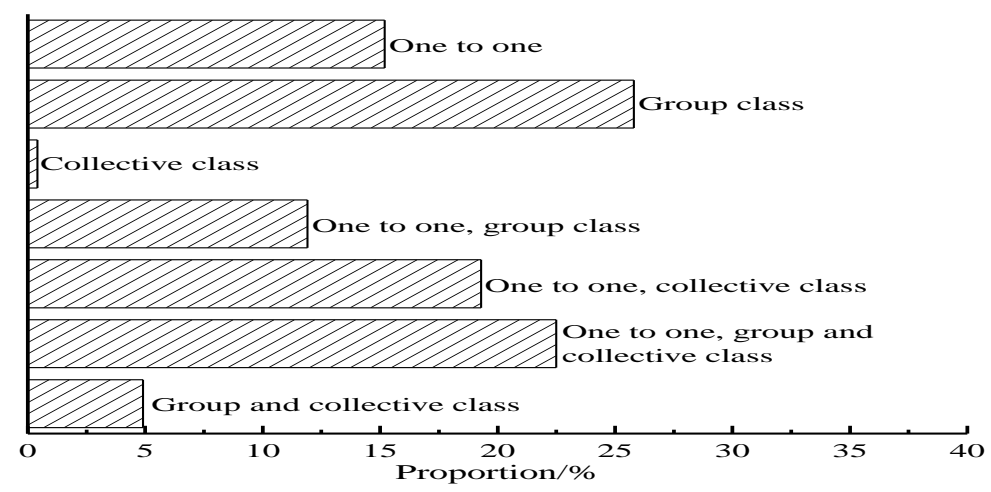

Figure 4. Yangzhou University piano course teaching method. 


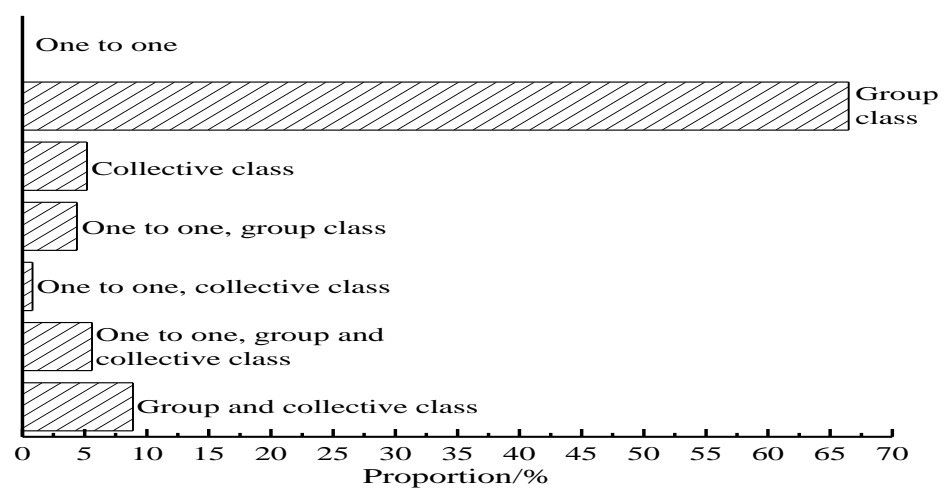

Figure 5. Yancheng Normal University piano course teaching method.

\section{Establishment of "Mooc" platform of piano teaching}

The piano video network teaching in Mooc can cultivate students' sense of competition, and the concrete implementation of Mooc platform in piano teaching has the principles of resources sharing, liberalization and teaching according to students' aptitude. The piano teaching in colleges and universities is more and more closely correlated to Mooc platform, which gives full play to the advantages and values of modern network teaching and enriches students' musical vision. Compared with the traditional teaching methods of group class and collective class, Mooc platform is easier for students to open the window of thinking and apply their abilities to practical application. The inter-school piano Mooc course can also be optimized and integrated with the resources among schools. The inter-school network connection is also established to integrate the piano resources of different networks. The regional piano Mooc course platform needs to be expanded and sharing learning of piano Mooc teaching shall be carried out.

\section{Conclusion}

Based on the network technology, this study explores the application of Mooc-based flipped classroom teaching mode in the teaching reform of piano course, and the concrete conclusions are as follows:

Mooc teaching has the characteristics of sharing, participation, liberalization and openness. The production of Mooc-based flipped classroom has made Internet knowledge production and teaching of dissemination break space-time limit.

The teaching platform of different schools has different uniform situations in the teaching materials of piano teaching, and the ability value of students is also different.

Teachers can make use of Mooc to expand piano subject practice and realize the teaching effect of flipped classroom that is an important form of Mooc teaching. Students can make up their own crux through flipped classroom pertinently so as to improve their ability to grasp artistic characteristics and style of piano. 


\section{References}

Egilmez, H. O. (2012). Music education students' views related to the piano examination anxieties and suggestions for coping with students' performance anxiety. Procedia-Social and Behavioral Sciences, 46, 2088-2093. http://dx.doi. org/10.1016/j.sbspro.2012.05.433

Gouzouasis, P., \& Ryu, J. Y. (2015). A pedagogical tale from the piano studio: Autoethnography in early childhood music education research. Music Education Research, 17(4), 397-420. http://dx.doi. org/10.1080/14613808.2014.972924

Griffith, K. R., Ramos, A. L., Hill, K. E., \& Miguel, C. F. (2018). Using equivalence-based instruction to teach piano skills to college students. Journal of Applied Behavior Analysis. http://dx.doi. org/10.1002/jaba.438

Hyrybeihammer, E. K. (2011). Narratives in teaching practice: Matti Raekallio as narrator in his piano lessons. Music Education Research, 13(2), 199-209. http://dx.doi. org/10.1080/14613808.2011.577767

Markert, B., Delakowitz, B., Fränzle, S., \& Wünschmann, S. (2017). Quality means decency-on the quality of teaching through accreditation of the course?. Environmental Science \& Pollution Research, 24(13), 1194011948. http://dx.doi. org/10.1007/s11356-015-5599-8

Nevra, K. M. (2014). Determination of the conformity of the work miniatures by Necil Kazım Akses with the objectives of the 2nd grade piano course of music teaching bachelor's degree program. Procedia - Social and Behavioral Sciences, 141, 951-960. http://dx.doi. org/10.1016/j.sbspro.2014.05.164

Villiers, F. D. (2012). The piano teaching situation from a student perspective: A South African qualitative study. Samus South African Music Studies, 31(1), 159-176. http://dx.doi. org/10.4314/samus.v31i1

Yeh, Y. L. (2018). An investigation of Taiwanese piano teachers' reflection on teaching challenges and pupils' learning difficulties. Music Education Research, 32-43. http://dx.doi. org/10.1080/14613808.2016.1249359

Ying, L. F. (2015). Tension release in piano playing: teaching alexander technique to undergraduate piano majors. Procedia - Social and Behavioral Sciences, 174, 2413-2417. http://dx.doi. org/10.1016/j.sbspro.2015.01.910

Yucetoker, I., \& Apaydinli, K. (2012). The situation and the importance of three-hand pieces in piano education. Procedia - Social and Behavioral Sciences, 51, 541-545. http://dx.doi. org/10.1016/j.sbspro.2012.08.203 